\title{
Developing a Framework of Government Future Flow Securitization Through Public Service Agency (Badan Layanan Umum)
}

\author{
I Putu Sukma Hendrawan, Bram Rahadyta, and Novriandini Ermaningrum \\ Government Asset Management (Lembaga Manajemen Aset Negara), \\ Ministry of Finance of The Republic of Indonesia \\ e-mail: iputusukma2@gmail.com
}

\begin{abstract}
There's emerging discussion about creative financing and diversification to close the funding gap of a massive development plan, with future flow securitization is one of the candidates. Since the first transaction undertaken in the late 1980's, future flow securitization still rarely used in Indonesia. Currently, such type of instrument was coming from the stateowned enterprise notably the state toll road enterprise securitized their future toll-road revenue flow. The Government of Indonesia could use future flow securitization as part of financing diversification, with rationalities of lowering the cost of capital through secured financing, risk-sharing to the private sector, and earmarking certain revenue for particular spending. Badan Layanan Umum/BLU (public service agency) could be the agent to conduct such financing, enabled by its characteristics of public service function mixed with corporatelike governance and also its nature of revenue center agency. The government would still be in complete control since BLU is within government arms' length and its financial management is not separated from the general budget. This study derives the potential use of future flow securitization through BLU. From the central government financial report, we found - on an aggregate basis - that there is a proper capacity of BLU's revenue to be securitized. This paper using qualitative method to construct a securitization-fit framework comprised of model, requirements, criteria along with features of the binding arrangement, required organizational settings, compartmentalization, and tranching.
\end{abstract}

Keywords-Future flow, Securitization, Public Service Agency, Creative Financing

\section{INTRODUCTION}

F INANCING development has always been a challenging issue within the public sector, particularly in developing countries where massive development agenda confront with limited fiscal capacity. Commonly, the gap between two represented by budget deficit - would be closed by the issuance of debt instrument, both short term in the form of treasury bills and long term in the form of treasury bonds. Usage of debt financing also instrumental in the Indonesia central government. According to the central government financial statement for year 2018 (audited), cash inflow from debt financing recorded at IDR782.31 trillion or took a proportion of almost 39\% of cash outflow from operating activities. In Table 1 Persistence usage of debt financing also delineated by year-on-year growth of cash inflow from debt issuance in the amount of $7.71 \%$.

In terms of diversification, debt financing majorly issued in form of local currency treasury bonds that took a proportion of $40.94 \%$ with others took form of local currency sharia treasury bonds, local currency treasury bills, foreign currency treasury bonds. Debt financing also diversified in terms of conventional and sharia based.

In terms of comparison with national output, Indonesia's central government deficit for year 2018 accounted for $2.19 \%$ of GDP which is recorded a positive trend compared with the previous figure in 2018 in the amount of $2.92 \%$. This positive performance represents a less risky figure of the central government budget and could be an indication of more robust tax revenue. Yet, budget deficit still an observable figure which is averaging 2.29\% of GDP from 2013 to 2018, meaning that discussion of financing policy is still relevant, concurrently with tax revenue strengthening policy. In terms of compliance with the regulation, these historical budget deficits are still below the $3 \%$ cap as per regulated in The State Finance Act, meaning that there is further financing diversification opportunity.

Diversification has been identified as consideration in addressing fiscal capacity and financial constraint. Stated in draft of National Medium-Term Development Plan 20202024 , in order to achieve 5.4\% - 6\% economic growth, massive amount of IDR37,447.6 trillion financing need to be available during planned period. Financing capacity of central government and state-owned enterprises would take maximum portion of $13.8 \%$ and $7.9 \%$ consecutively, which the remaining are would subject to deepening of financial market, financial inclusiveness, and optimization of financing alternatives through development of innovative financing. Ministry of Finance, as the fiscal authority, already included development of innovative financing as strategic objectives during 2020-2024.

One of innovative financing alternative is using secured financing instrument which involved collateral. In the current financing portfolio of Indonesia's central government, involvement of collateral or underlying asset are limited and narrowly applied in order to comply with sharia principal, such as utilization of sale and lease back transaction of state asset and infrastructure projects as underlying transaction of 
The $1^{\text {st }}$ International Conference on Business and Engineering Management (IConBEM)

February $1^{\text {st }} 2020$, Institut Teknologi Sepuluh Nopember, Surabaya, Indonesia

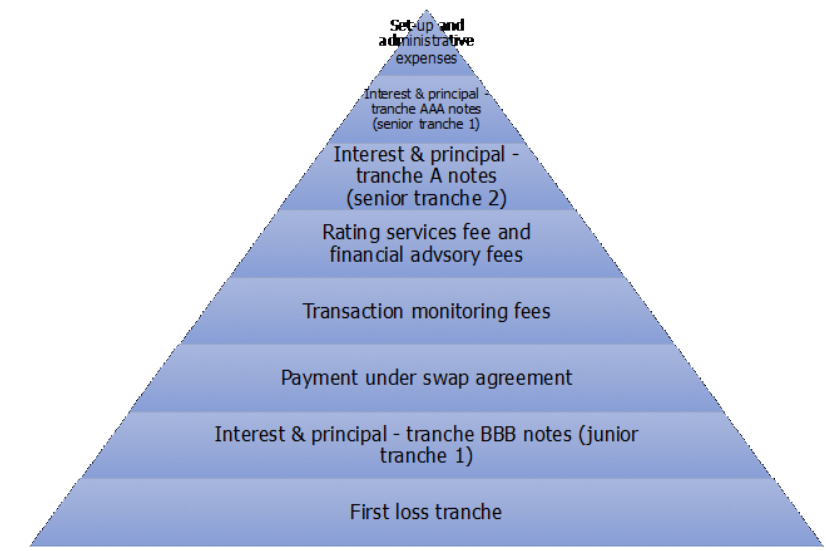

Source: Securitisation in Luxembourg, A Comprehensive Guide Figure 1. The "Waterfall" Payment Sequence.

sukuk issuance. This narrow utilization raises an opportunity to use secured financing as a diversification instrument. Using a lesson learned, from other countries such as Latin America countries and diversification conducted by Indonesia's state toll road corporation, secured financing using future flow receivables [1] as the underlying transaction could be a relevant discussion.

Many literatures and research affirm innovative attribute of future flow securitization. According to [2], future flow securitization was emerged as important financing alternative for the public sector since the mid-1980s with rationale to lowering cost of financing, by providing future revenue flows as collateral and conduct secure arrangement as risk mitigation of commonly associated public sector borrowing risks. This rationale was based on risk-return trade-off and logic of involvement of collateral on borrowing. [3] stated that collateralized bonds generally considered safer (less riskier) than general debenture unsecured bonds, hence it would offer lower yields. Future flow securitization is considered as an innovation in the bond market. [3] describe an example of innovation in the bond market by issuance of asset-backed bonds by Domino's Pizza which payment is serviced by particular revenue from its pizza franchise.

Another argument is raised by [4] emphasizing a different perspective in defining securitization. Though the end-result of securitization is financing, securitization is not "financing" as such because the entity securitizing its assets is not borrowing money but selling a stream of cash flows that were otherwise to accrue it. According to IDX Statistics November 2019 Future flow securitization and other asset-backed securities are apart from the current mainstream of financing instruments, with an outstanding value of IDR10,387 trillion. This figure is relatively modest - asserting non-mainstream or innovative attribute - contrast with outstanding value of corporate bond/sukuk at IDR445.97 trillion, government bond/sukuk at IDR2,770.19 trillion, and market capitalization of stock at IDR6,919.50 trillion. Such an attribute is also confirmed by a fractional number of asset-backed securities issued at 15 compared to 98 series of government bond/sukuk, 803 series of corporate bond/sukuk, and 664 listed stocks. Furthermore, only 2 future flow securitization instruments that are currently listed in the IDX.

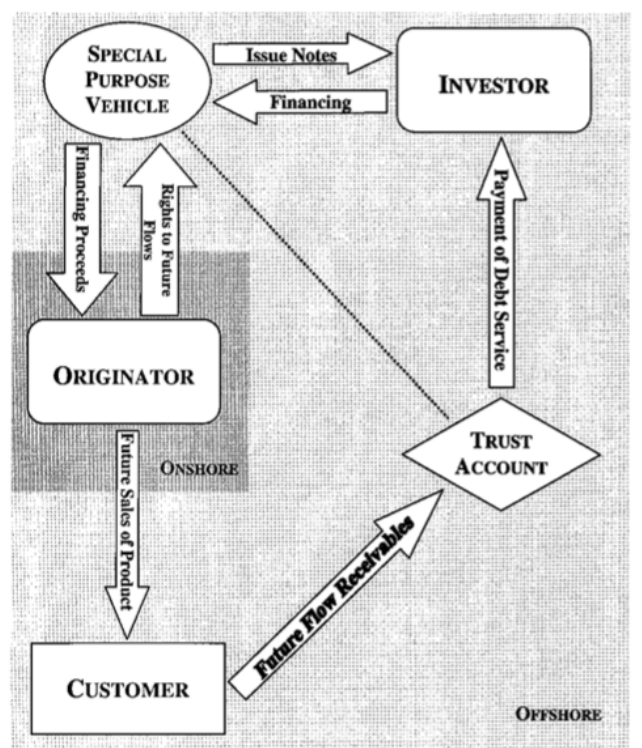

Source: Chalk (2001)

Figure 2: Structure of Typical of Future Flow Receivables

Any type of government revenue, ranging from revenue from non-exchange transactions such as tax and excise to revenue from exchange transactions such as revenue from natural resources contract, government asset lease, dividend, and revenue from service conducted by government units, could be used for underlying of future flow securitization. According to previous journals and papers, it were foreign generated income that used as the underlying transaction, hence securitization instrument issued on those foreign currency. Such securitization was based on rationale of trapping those foreign currency denominated income using offshore special purposed vehicle so that investor would not be exposed to conversion rate risk. From the issuer perspective, this cash trapping feature could impact on lowering cost of capital by reducing issuer default probability. Even though major number of securitizations used foreign generated revenue, this paper is focusing on domestic exchange generated revenue from service conducted by government units, particularly Public Service Agency [5].

According to Government Regulation number 23 of 2005 , as revised with Government Regulation number 74 of 2012, BLU is a type of government unit that:

A. embedded with financial management flexibility attribute,

B. expected to be managed with proper business practice based on efficiency and productivity,

C. having a service generated orientation without merely focusing on profit-making.

Financial flexibility also means that BLU should be selfsustained. As a ramification of its flexibility, BLUs are not required to pool their cash to general government account even though its financial management is not separated from the general budget, like state-owned enterprises that are clustered as segregated state assets. This flexibility and a waiver treasury single account concept excluded BLU's capacity from the consideration of resource envelope during the annual budget preparatory. 
The $1^{\text {st }}$ International Conference on Business and Engineering Management (IConBEM)

February $1^{\text {st }} 2020$, Institut Teknologi Sepuluh Nopember, Surabaya, Indonesia

Table 1.

Debt Financing Portfolio of Indonesia's Central Government

\begin{tabular}{lllr}
\hline \hline \multicolumn{1}{c}{ Currency } & \multicolumn{1}{c}{ Basis } & \multicolumn{1}{c}{ Type of Debt } & $\%$ of Total \\
& & Financing & \\
\hline Local & Conventional & Treasury bills & $18.28 \%$ \\
currency & & Treasury bonds & $40.94 \%$ \\
& Sharia & Treasury bills & $6.61 \%$ \\
& & Treasury bonds & $12.38 \%$ \\
Foreign & Conventional & Treasury bonds & $12.51 \%$ \\
currency & Sharia & Treasury bonds & $5.48 \%$ \\
\hline \hline
\end{tabular}

Of course, the Ministry of Finance could withdraw or borrow the excess cash capacity of BLU according to article 29 of Government Regulation number 23 of 2005, to close short-term cash insufficiency, for instance. Such a feature reconfirms that BLU's are within the reach of state treasurer arm's length. Yet, we still offering another instrument to strengthen the contribution of BLU's within general treasury policy, concurrently to realize financing diversification opportunity.

We found that there is a proper capacity of BLUs in terms of its free cash flow which could be securitized. During 20142018, BLUs' free cash flow is in the amount of IDR8.81 trillion on average. This aggregate free cash flow was growing approximately $16.5 \%$ on a compounded basis during the same period. Meanwhile, the growth of real sector BLU's (goods and service generated and enclave management BLUs) recorded at $7.01 \%$ on average. Such stable growth could be an indication of a going concern environment that is very much fundamental within future flow securitization, according to Fitch Rating.

The general treasurer, Ministry of Finance, could utilize BLUs capacity to diversify the central government financing portfolio. A special purposed vehicle - could be in the form of another BLU - would issue securitization instrument in which repayment would be serviced by BLU's future flows. To conduct such a strategy, the government would need a framework which determines the scheme or structure of the instrument and enabling the assessment of BLUs and their operation in terms of securitization feasibility. This paper would contribute to practice and policymaking, this framework which we believe could be suitable for the piloting phase of future flow securitization in the public sector through BLUs. Our framework would comprise of (1) the structure of future flow securitization through BLUs, (2) securitization feasibility assessment methodology using financial performance rating and rating notching uplift based on particular criteria.

The remainder of this paper would be organized as follows, section II provides methodology and some concept we adopt in this paper, section III would present result of our work, and this paper would be closed by statement of conclusion and research limitation in section IV.

\section{LITERATUR REVIEW}

Literature review would be our main methodology in this paper which would see us using a qualitative research strategy. Similar methodology also used in previous research conducted by Chalk (2002) which scrutinized the potential role for securitization of public sector revenue flows in the Philippines.

\section{A. Securitization}

Securitization is a structured financial instrument which means a financial instrument structured or tailored to the needs of issuer as opposed to a generic, on-tap product (Kothari, 2006). From the investor's perspective, it also means an instrument structured to meet the risk-return and maturity needs of the investor rather than a simple claim against entity or asset. Furthermore, [4] presented some broad features of securitization as follows:

1) Receivables that are securitizable

Traditional securitization requiring the entity to have substantial investment in receivables which are already provided, reasonably predictabl e, and diversified.

2) The creation of security

The very purpose of securitization is to ensure marketability to financial claims. This purpose would involve two postulates, the legal and systemic possibility of marketing the instrument and the existence of a market for the instrument.

3) Special purpose vehicle

The idea of special purpose vehicle (hereafter referred as SPV), is to clothe an asset(s) with the garb of incorporation, so that the one who owns the securities of the SPV really owns the assets, no more and no less. An operating company, which might hold other assets and other liabilities, would not fit ho hold securitized assets since these other assets and other liabilities might be interfere such exclusivity afore described. SPV is a legal entity but a substantive non-entity which makes a SPV bankruptcy remote.

4) Re-distribution of risks

In most securitization transactions, the risks are transferred using a structured fashion: Who takes the first hit, the next one, and thereafter until the last one is concerned or affected. Based on these priorities, risks are referred to as first loss risk, the second or subsequent loss risk, and so on. The one who takes the first loss risk is a junior holder, and the one who takes subsequent risk is a senior one

\section{5) Rating}

The need for rating of securitized products is clearly appreciated; investors expose themselves solely on the quality of the assets with a limited right of looking back at the originator. Therefore, it is natural that the investors must understand the quality of the portfolio. In some jurisdictions, regulations require asset-backed offerings to be rated. As the motivation for securitization is to see a rating upgrade, it is common to see securitization transactions rated.

Distribution of risk through structuring process is one of central element of securitization transaction. In its comprehensive guide of securitization in Luxembourg, In Figure 1 [6] presented the "waterfall" payment sequence depict the order of the cash return on assets, which allows both interest, transaction-related fees, and the repayment of the securities issued. 
The $1^{\text {st }}$ International Conference on Business and Engineering Management (IConBEM)

February $1^{\text {st }}$ 2020, Institut Teknologi Sepuluh Nopember, Surabaya, Indonesia

Table 3.

Highlight of BLUs' Revenue (aggregate basis)

\begin{tabular}{lccccc}
\hline \hline (In million IDR) & 2018 & 2017 & 2016 & 2015 & 2014 \\
\hline Revenue from core operation & 48.82 & 44.25 & 39.47 & 32.47 & 26.50 \\
Grant revenue & 0.09 & 0.17 & 0.06 & 0.10 & 0.09 \\
Revenue from cooperation & 1.56 & 0.58 & 0.85 & 0.780 & 1.23 \\
Transfer from central government & 0.23 & - & - & - & - \\
Other Income & 5.59 & 2.35 & 1.56 & 1.97 & 1.86 \\
Total revenue & 55.09 & 47.34 & 41.95 & 35.32 & 29.68 \\
\hline \hline
\end{tabular}

Source: Central Government Financial Report (processed)

Table.4.

Aggregate BLUs' Free Cash Flow (IDR trillion)

\begin{tabular}{lcccc}
\hline \multicolumn{5}{c}{ Aggregate BLe } \\
\hline 2018 & 2017 & 2016 & 2015 & 2014 \\
\hline 11.23 & 10.18 & 9.08 & 7.47 & 6.09 \\
\hline \hline
\end{tabular}

Table 5.

Scoring Categorization of BLU Based on Performace

\begin{tabular}{ccccc}
\hline \hline \multirow{2}{*}{ Aspect } & \multicolumn{3}{c}{ Financial ratio } \\
\cline { 2 - 5 } & $\mathrm{x}<6.5$ & $6.5 \leq \mathrm{x} \leq 13$ & $13<\mathrm{x}$ \\
\hline \multirow{2}{*}{$\mathrm{m}<3,5$} & $\mathrm{~A}$ & $\mathrm{~B}$ & $\mathrm{C}$ \\
$\mathrm{c}$ & $3.5 \leq \mathrm{y} \leq 7$ & $\mathrm{D}$ & $\mathrm{E}$ & $\mathrm{F}$ \\
& $7<\mathrm{y}$ & $\mathrm{G}$ & $\mathrm{H}$ & $\mathrm{I}$ \\
\hline \hline
\end{tabular}

The underlying portfolio's cash flow is used to fill or refill the requirements of the top tranche (senior tranche). The surplus cash flow then flows down to fill or refill the requirements of the second tranche (i.e. junior, mezzanine, and subordinated), and so on. This process will last until the cash flow is exhausted. The first-loss tranche at the bottom will receive the residual cash flow after all prior claims have been satisfied. The residual cash flow thus represents a high rate of return if the underlying assets are performing well, and vice versa.

It stated some essential terminology of securitization [4], as follows:

1) Originator: the entity securitizing its assets, which name signifies that the entity was responsible for originating the claims ultimately to be securitized;

2) Asset-backed securities: the securities that are backed by specific assets and repayable from such assets only.

3) Existing asset securitization vs future flow securitization: The securitized assets could be either existing receivables or receivables to arises in the future.

4) True sale: Legal transfer of receivables to separate entity, not merely a financing or borrowing against the security of receivables.

5) Special Purpose Vehicle (SPV): The entity that created solely for the purpose of the transaction. SPV would be the intermediary that hold the receivables for the benefit of the end investors. SPV is also the instrument issuer.

6) Collateral: The Asset or receivables that back up the securities. Different type of asset-backed securities.

7) Pass through certificates: The securities represent a direct claim of the investor on all that the SPV collects from the receivables transferred to it.

8) Pay through certificates: Alternative of pass through certificates which the SPV reconfigure the cash flow by reinvesting it, so as to pay the investors on fixed dates, not matching the dates when the transferred receivables are collected by the SPV.

9) Bankruptcy remoteness: The transfer of the assets by the originator to the SPV is such that even the originator goes bankrupt, or falls into other financial difficulties, the rights of the investors on the assets held by the SPV are not affected.

\section{B. Future Flow Securitization}

According to Kothari (2004), future flows transaction relates to assets that expected to exist, while traditional assetbacked transactions relate to asset that already exist. In a future flow securitization, originator transfers the stream of cash flow which will be dedicated to making payments to investors before the cash flow reaches the originator.

It using electricity company and an airlines company as examples. [4] Electricity company securitizing its electricity revenue and airlines company securitizing its air ticket sales, which right of such revenue doesn't exist today and the very existence of revenue would be over a period of time presuming the continuity of revenue-generating activities. Future flows securitization has some key features which differ from the existing asset securitization [4], as follows:

1) Uncertain receivables: Future flow receivables are uncertain and largely unpredictable. The originator transfers a certain portion of the receivables which based on a past track record and after applying stress test. The originator retains the excess portion.

2) Cash flow trapping: SPV as the trustee should have physical trapping of the cash flows generated by the subject receivables, before they are routed to the originators.

3) Prioritization of transferee: SPV as the transferee, by virtue of the cash flow trapping, gets priority over even the operating expenses of the transferor, the originator.

4) High extent of over-collateralization: Such collateral is a safeguard against the fact that the investors are likely to be affected by the performance risk of the originator.

5) Restrictions on the borrower's business: Being a quasilending type exposure, a future flow deal typically places restrictions on the borrower's ability to borrow and create encumbrances or liens, and similar covenants.

6) No originator independence: Unlike other type of assetbacked transaction that are structured to be independent of the originator (except for servicing), future flows deals are substantially dependent to the originator.

7) Not off-balance sheet

It explain the taxonomy of risk commonly associated with public sector borrowing [2], which as the repercussion would be associated with future flow securitization in public sector, as follows:

1) Performance risk: whether the originator capable of continuing operations and generating cash flows to service the securitized debt, even if it is in default on other debt obligations or if it is undergoing bankruptcy proceeding or reorganization. 
The $1^{\text {st }}$ International Conference on Business and Engineering Management (IConBEM)

February $1^{\text {st }} 2020$, Institut Teknologi Sepuluh Nopember, Surabaya, Indonesia

2) Receivable generation risk: whether the originator be able to continue generating the sales necessary to meet the debt service cost.

3) Diversion risk: the likelihood of the originator will choose to - or be forced to - divert delivery of its product to another source

4) Obligor risk: the underlying risk to the performance of end provider of the pledged revenue source.

5) Exchanger rate risk: the mismatch between the receivable inflows and the debt service outflows.

6) Tax risk: whether the tax treatment of various components of securitization arrangement change.

7) Transfer and convertibility risk: for instance, the restrictions that limit outflow of foreign currency which would impact foreign currency debt repayments by domestic borrowers.

present the structure of typical securitization of future flow receivables in Figure 2 [2]

\section{ANALYSIS}

According to the literature review afore-described, we develop a framework on how future flow securitization within the public sector would took structure, as follows setting up the parties, the securities, transferring the receivables, and security and risk.

\section{A. $\quad$ Setting Up The Parties}

\section{1) The Originator}

Originator is the entity securitizing its assets, which name signifies that the entity was responsible for originating the claims ultimately to be securitized. This entity generates an income stream on future-basis. The originator can isolate any of the future revenue-based and use these for a securitization. In the context of this study, we provide alternatives of which party that would take role as the originator.

a. The BLU as the entity that generate income stream on future basis.

b. Ministry of Finance c.q. Directorate General of Treasury as the general treasurer and financial regulator of BLUs.

The first alternative would be much more natural since the determination on the very existence of BLU's capacity is conducted by BLUs themselves. On the other hand, since our study is emphasizing on the capacity of BLUs on aggregate basis, such approach accentuated on individual BLU's level would be more convolute.

The second alternative is more applicable on addressing the shortcoming of the first alternative considering the position of DG Treasury as a general treasurer and financial regulator of BLU which is attributed with proper control and authority of BLU's revenues. To conduct this alternative, DG Treasury needs to pool BLU's securitizable revenues through policy and regulation.

We found that BLUs have proper revenue capacity to be securitized. Based on Government Financial Report of the year 2014 - 2018, it is stated that average revenue of BLUs on aggregate basis is approximately IDR41.9 trillion with total expenditure about IDR32.58 trillion that consist of IDR29.26 trillion Operating Expenditure and IDR3.3 Trillion of Capital Expenditure. This structure of income and expenditure lead to free cashflow of BLU during 2014-2018 averagely amounted to IDR9.31 Trillion.

There are several categories of BLU's revenue as shown in the following Table 3. Future flow receivables of BLU commonly induce from its services according to the core business of each BLU. In this research, we are going to use only free cash flow that coming from excess of public services income reduced by all its expenditure to illustrate the capacity of BLU free cash flow to be securitized.

We use the assumption of Operating expenditure averagely $69 \%$ of related income and capital expenditure is averagely $8 \%$ of related income. Using this basic assumption, and public service revenue as the Table 3 , free cash flow from Public Service Income for the year $2014-2018$ is IDR8.81 trillion as in detail is shown by the Table 4

\section{2) The Special Purpose Vehicle}

Special Purpose Vehicle (SPV) is the entity that created solely for the purpose of the transaction. SPV would be the intermediary that hold the receivables for the benefit of the end investors. SPV is also the instrument issuer.

The idea of SPV is that an operating entity, which might hold other assets and other liabilities, would not fit ho hold securitized assets since these other assets and other liabilities might be interfere such exclusivity afore-described. SPV is established separately from the originator so that it is not treated as a subsidiary of the originator and not affected by the insolvency of the originator. SPV is a legal entity but a substantive non-entity which makes a SPV bankruptcyremote. Its main task is to isolate/trap the future receivables that are used to repay the securities.

In the context of this study, we provide alternatives of which party that would take role as the SPV with main requirement that such SPV would be a separated entity to the originator.

a. First alternative is that DG Treasury form a new BLU solely function as SPV.

b. Second alternative is that DG Treasury form or assign a separated legal entity from the government solely function as SPV.

The advantage of the first alternative is that the simplicity of the BLU establishment which merely require a ministry regulation or decree. This alternative comes with shortcoming that there is limited capability of the BLU because they need to comply with highly regulated government environment. Furthermore, such segregation of duties between originator and SPV cannot be fully realized since the BLU is regulated and controlled by DG Treasury of which we propose to be the originator. Such shortcoming would be addressed by the second alternative that comes with the advantage that the SPV will be legally separated from the government.

The legally separated SPV in this context could be in the form of establishment of new corporation that solely for the purpose of securitization transaction or kind an assignation of already established corporation. In our perspective, the former would be suit to the pass-through certificate model. The later would suit the pay through certificate model since such corporation already possessing proper resources and capability to reconfigure the cash flow coming from the originator. But, the later is also comes with the issues of the very definition of SPV. 
The $1^{\text {st }}$ International Conference on Business and Engineering Management (IConBEM)

February $1^{\text {st }}$ 2020, Institut Teknologi Sepuluh Nopember, Surabaya, Indonesia

3) The Securities

\section{a. Issuing The Securities}

The SPV issues securities to investors to fund the purchase of the isolated future receivables from the originator. The securities are usually bonds or notes, and may be issued in several structured tranches, that is different classes of securities with different payment priorities and characteristics, such as different credit rating or interest rates.

The securities substantially a contract that should disclose information as follows:

1. The revenue that will be the underlying asset used to service the repayment of securities.

2. The model, whether it is pass through certificate or pay through certificate. It would affect the payment schedule of the instrument to the investor.

3. Other features, such as overcollateralization for instance the obligation to the originator to provide cash reserve and restriction on the borrowers business or covenants.

The securities in this context are classified as asset backed securities (ABS), which the asset in this case is the future flow from BLU's business. Such ABS form could refer to practices that already exist in Indonesia, namely the Asset Backed Securities Collective Investment Contract originated by PT Jasa Marga (Persero) Tbk

b. Tranching The Securities

To optimise the risk profile of the securities and therefore maximise the range of investors to whom they can be sold, the securities are divided into different classes. These typically consist of several sequential tranches with differing priorities as to payment of principal and interest and carrying different rate of interest. The more senior tranches have the right to priority of payment over more junior tranches, but the more junior tranches carry a higher rate of interest. Such division is conducted using the "waterfall" payment sequence.

In the context of this study, we propose the adaptation of performance appraisal framework currently regulated by DG Treasury to categorize BLU's revenue into proper tranches.

First and foremost, we categorize BLUs based on their performance using Regulation of the Director General of Treasury for particular BLUs sector. The performance criteria under this regulation comprise of financial ratio aspect and compliance aspect.

The regulation is purposed to appraise BLUs performance using weighted average of financial performance measure and compliance aspect measure which is presented in form of a score. The financial aspect comprise of financial ratios for instances, liquidity ratio, rentability ratio and operating efficiency ratio. On the other hand, the compliance aspect is related to corporate governance aspect of the BLUs. The highest score of financial ratio aspect is 19,5 mean while it is 10,5 point for compliance aspect.

For the purposes of tranching, we conduct the categorization of BLUs based on the score aforementioned into nine groups presented in $3 \times 3$ quadrant as Table 5

This categorization would be used as the baseline to conduct further assessment which benchmarked from the framework developed by Fitch Rating.

\section{Transferring the Receivables \\ 1) Classes of Receivables}

Receivables are rights in respect of financial obligations arising from the obligation of a debtor to pay its creditor amounts in respect of a debt.

\section{2) The Transfer of The Receivables form The Originator}

The originator transfers the receivables to the SPV. The form of transfers depends on the jurisdiction. The most common method of transferring receivables in a securitisation is assignment. Therefore, the SPV pays the transfer price for the receivables immediately on the transfer.

Future flow receivables are uncertain and largely unpredictable. The originator transfers a certain portion of the receivables which based on a past track record and after applying stress test. The originator retains the excess portion. 3) Avoiding The Transfer Being Re-Characterized

While the character of the transfer of the receivables may seem straightforward, some of the commercial requirements of the transaction may result in doubt being cast on whether there has been a valid and effective transfer of title to the receivables. For example, if the transaction has certain characteristics, such as the originator having right to repurchase receivables to end the securitisation, the intended transfer may be recharacterized as a loan with a grant of security, rather than a true title transfer. The following features may help to avoid an intended title transfer being recharacterized:

a. The transfer agreement expressing as clearly as possible that the transfer is a sale.

b. The transfer agreement clearly documenting the passing of ownership risk to the SPV

c. The transfer agreement not providing post-transfer rights to the originator over funds generate from the transferred receivables.

This issues should be clearly and explicitly stated in the contract.

\section{4) Establisihing The Regulation and Applicable Law}

Identifying the applicable law relevant to the underlying transactions contemplated by the transaction documents is essential to determine the formalities that must be complied with, which is going to be limitation of this study since we didn't conduct a complete legal framework analysis.

However we did identify that financing activities is under the authority of Ministry of Finance as the general treasurer (according to Government Regulation Number 45 of 2013 about The Implementation of State Budget). Furthermore, we also identify that there is a newly implemented Minister of Finance Regulation number 82 of 2018 about Cash Management and Investment By Public Srvice Agency.

D. Risk

1) Credit Enhancement

The arranger in a securitisation may apply various credit enhancement techniques to improve the credit rating of the securities so they appeal to the investors. One widely used method of credit enhancement is over-collateralisation, which is the originator transfer receivables of a greater value than the consideration paid by the SPV. Other common methods of credit enhancement include: 
The $1^{\text {st }}$ International Conference on Business and Engineering Management (IConBEM)

February $1^{\text {st }} 2020$, Institut Teknologi Sepuluh Nopember, Surabaya, Indonesia

a. Creating retained spread : the SPV retains the excess income as a reserve fund to cover costs and expenses and so improve the creditworthiness of the securities

b. Creating subordinated tranches: senior tranches of securities is credit enhanced by providing the holders with priority of payment over the more junior tranche holders.

c. Insurance: insurance enhance the creditworthiness since it ensures source contracts to make payments due on the securities issued by the SPV if the SPV is unable to do so. In this context the insurance can be provided by DG Treasury itself or be assigned to insurance company

2) Risk Management

Because the SPV is usually structured with very little residual capital, it may become subject to short-term cash flow timing problems, that is known as liquidity risk and arises when the SPV failing or late to pay their debts. To manage such risk in the structure, the SPV must have adequate cash flows to pay amounts due on time. The following are common methods for providing it by:

E. A loan from the originator to the SPV

1) Cash reserve funds

When the SPV hold on to certain funds and invest them in highly liquid and secure assets. A cash reserve fund may arise by retaining amounts on an ongoing basis that it receives from the receivables that are above the amounts due on the securities

\section{2) Further Assesment}

Based on the previous research there is some framework that could be adopted in this study. First and foremost we make some criteria to categorize various future flow transaction. Secondly, the assessment should be made to future flow transaction based on their performance, product and sovereign risk in order to rank future flow receivable transaction from the most secure to the least secure. The lower in the hierarchy they are, the more future flow receivable transactions require safeguard to improve their credit ratings. However, it is still possible to securitize even the least secure future flow receivables.

We use the framework developed by Fitch Ratings to conduct further assessment of future flow securitization which is comprise of key rating drivers as follows:

a. Rating threshold which is determined by the potential diversion risk and some degree of performance risk by the originator.

b. Originator's credit quality which is measured by LocalCurrency (LC) Issuer Default Rating (IDR) of the originator. It is possible to notching uplift from LC IDR based on the assessment of attributes and characteristic of future receivables include the proportion of future flow debt to total debt of originator, characteristic of the receivables and their volatility and debt service coverage ratio (DSCR) under sensitivity scenarios.

c. Going concern assessment that measure likelihood that the business remains a going concern and keep continuing in generating the underlying cash flow.

d. Potential Redirection/Diversion Risk that asses potential interference by the government or the originator in terms of incentives and ability to interfere.

This rating will be useful for determining the tranches of transaction in future flow securitization.

\section{CONCLUSION}

This paper contribute to practice and policymaking by providing a framework which we believe could be suitable for the piloting phase of future flow securitization in the public sector through BLUs. Our framework comprise of (1) the structure of future flow securitization through BLUs, (2) securitization feasibility assessment methodology using financial performance rating and rating notching uplift based on particular criteria.

This study derives the potential use of future flow securitization through BLU. From the central government financial report, we found - on an aggregate basis - that there is a proper capacity of BLU's revenue to be securitized.

We propose the adaptation of performance appraisal framework currently regulated by DG Treasury to categorize BLU's revenue into proper tranches. In this method we categorize BLUs based on their performance using Regulation of the Director General of Treasury for particular BLUs sector comprise of financial ratio aspect and compliance aspect. The result of this performance appraisal is BLU score. We did make a grouping based on the score into a nine box quadrant which measure the baseline of securitizable framework.

Furthermore we propose the adoption of Fitch Rating framework to conduct further assessment or robustness test of securitizable framework.

\section{REFERENCES}

[1] Fitch Ratings, "Future Flow Securitization Rating Criteria," no. July, pp. 195-225, 2019, doi: 10.1201/9781439802595.ch8.

[2] N. A. Chalk and International Monetary Fund., The Potential Role for Securitizing Public Sector Revenue Flows : an Application to the Phillipines. Washington: International Monetary Fund, 2002.

[3] Deloitte, "Securitization Structured finance solutions," 2018.

[4] V. Kothari, Securitization : the financial instrument of the future, Second edi. Hoboken New Jersey: John Wiley \& Sons, 2015.

[5] Directorate General of Treasury of The Ministry of Finance of The Republic of Indonesia, Minister of finance republic of indonesia, no. 27. 2014.

[6] PWC, "Securitisation in Luxembourg A comprehensive guide," 2019 . 